\title{
WHICH SKILLS, COMPETENCIES AND ATTITUDES ARE EMPLOYERS LOOKING FOR IN RECRUITMENT PROCESS IN LATVIA?
}

\author{
Anita $\mathrm{LICE}^{1^{*}}$, Biruta SLOKA ${ }^{2}$ \\ ${ }^{1}$ Faculty of Pedagogy, Psychology and Art, University of Latvia, 19, Raina Blvd., LV-1586, Riga, Latvia; \\ Employers' Confederation of Latvia, 4, Raina Blvd., Riga, LV-1050, Latvia \\ ${ }^{2}$ Faculty of Business, Economics and Management, University of Latvia, 5 Aspazijas Blvd., Riga LV-1050, Latvia \\ *E-mail:anita.lice@gmail.com
}

\begin{abstract}
Purpose - the purpose of the study is to evaluate the opinion of employers on the importance of employability competencies in recruitment in Latvia, considering increasingly global and changing labour market.

Research methodology - total of 750 companies participated in this research. A list of 17 skills, competencies and attitudes, important for individual employability in changing labour markets, was rated using a four-point Likert scale.

Findings - the research results show that employers value attitudes, emotional and self-management competencies the most when hiring potential employees, which are followed by social competencies. Although academic skills were assessed as the least important in the list of all competencies, the majority of employers consider academic skills important in the recruitment process.
\end{abstract}

Research limitations - as this research is not sector-specific, it is limited only to those competencies that can be equally applicable to all occupations.

Practical implications - research provides valuable, easily acquirable information for various stakeholders in the area of human resource planning and development, including educational institutions which aim to update programmes to facilitate graduate employability.

Originality/Value - research offers three complex factors explaining the elements of individual employability, based on empirical analysis.

Keywords: employability, hiring, labour demand, personnel management, recruitment.

JEL Classification: M51.

Conference topic: Contemporary Organizations Development Management.

\section{Introduction}

The importance of planning human resources in every business is increasing due to increase in global competition and labour market flexibility. Recruitment is one of the important parts of an employer's human resource planning, as it serves fulfilling employer's needs by enabling it to have a set of employees which can ensure continued operation and fulfilment of organization's objectives. According to Harvey (2005), employers are looking for recruits who are going to be effective in a changing world. They want intelligent, flexible, adaptable employees who are quick to learn and can work on a range of tasks simultaneously (Harvey, 2005), or, in other words, will be employable throughout career. Harvey (1999) defines employability as a propensity of graduates to exhibit attributes that employers anticipate will be needed for the effective future operation of their business organization. Considering the changing labour market, defining employability attributes is a very challenging task. According to the World Economic Forum, $42 \%$ of core skills will change between 2018 and 2022 (World Economic Forum, 2018). This has implications for different stakeholders in the area of human resource planning and development, including students, educational institutions, employees and employers. Students have to be prepared for becoming professionals in occupations that probably still do not exist. Educational institutions face the challenge to support students in preparing for turbulent careers and lifelong learning. Employees have to understand and adjust to the trends in changing job requirements by becoming self-directed learners. Employers face the challenge to recruit and keep the best candidates for changing jobs. In Latvia, these groups of stakeholders have been informed about changing labour market demands and required competencies by various employers' surveys, however, they have rarely been representative, and none have analyzed the competencies

(C) 2019 Authors. Published by VGTU Press. This is an open-access article distributed under the terms of the Creative Commons Attribution (http://creativecommons.org/licenses/by/4.0/) License, which permits unrestricted use, distribution, and reproduction in any medium, provided the original author and source are credited. 
that are important for sustainable employability in changing labour market conditions. Therefore, this research aims at evaluating, which of the skills, competencies and attitudes determining individual employability are most important in the recruitment process in Latvia from employers' perspective by a nation-wide, representative survey.

The paper is structured as follows: first, the methodology is explained, then the theoretical findings are presented, which are followed by the empirical findings. The results of the research and the relationship of the current research to prior research are discussed in a separate chapter which is followed by the main conclusions.

\section{Methodology}

The methods of research included the analysis of scientific publications and a survey of employers $(n=750)$.

A sample for the survey was created by multistage cluster sampling method. The answers to the questionnaire were collected by the research centre SKDS Ltd. First, the companies which were in the database of "SKDS" were contacted, then the companies from the public databases of companies were selected according to the random sampling method. The data were collected in two phases: 1) from 27.03.2017 until 04.04.2017, when 499 internet questionnaires were collected, and 2) from 05.04.2017. - 03.05.2017, when 251 telephone interviews were conducted by 19 interviewers. For telephone interviews, there were 587 cases of non-response: in $87.6 \%$ of these cases respondents didn't want to participate in the interview, 7\% - didn't have time and 5.5\% stopped answering during the interview. The collected data were weighted according to the statistics of the Central Statistical Bureau of Latvia of 2015 on the distribution of companies by industry, size and location of a company to ensure their representativeness. Considering the size of the general population, the margin of error (MOE) at $95 \%$ confidence level is $+/-4.0 \%$.

To assess the importance of certain skills, competencies and attitudes in the recruitment process, the Likert-type question was included in the questionnaire. The scale was bi-directional with 4 possible answers. An option "difficult to answer" was included as well. The list of 17 items to be assessed was elaborated, based on the list of employability attributes which resulted from operationalisation of the CareerEDGE employability model (Pool, Qualter, \& Sewell, 2014; Pool \& Sewell, 2007). The list of items was adapted to the needs of the target audience of employers and the limitations of the questionnaire. Additional questions on the profile of companies were included: sector, region, number of employees, and whether the company have had trainees during the last 5 years.

For data analysis of the survey results, descriptive statistics were used: indicators of central tendency or location (arithmetic mean, mode, median), indicators of variability (range, standard deviation, standard error of mean), relative frequencies, multivariate statistical analysis (factor analysis and correlation analysis), as well as other methods of statistical analysis (Kruskal-Wallis test or one-way ANOVA).

\section{Theoretical findings}

In the academic research concerned with the impact of labour market trends of the 21 st century, two main strands could be identified: one focussing on the future skills demands and other on the ways they should be addressed in education systems. According to Humburg, van der Velden and Verhagen (2013), the main trends that are shaping the future skills needs our knowledge society, increasing uncertainty, ICT revolution, high performance workplaces, globalization and change of economic structure. They require that graduates possess professional expertise, flexibility, entrepreneurship competencies and international orientation, and are able to innovate and manage knowledge, as well as mobilise human resources (Humburg et al., 2013). Other researchers offer other combinations of necessary competencies for enhanced employability in the changing labour market. For example, Fugate, Kinicki and Ashforth (2004) argue that the employability embodies a synergetic combination of career identity, personal adaptability, and social and human capital. Researchers Yorke and Knight (2004) have proposed a well-known and respected in the field model of four inter-related components of employability - USEM: (1) understanding; (2) skills (subject specific and generic); (3) efficacy and beliefs (and self-theories generally); and (4) metacognition (including reflection). Bridgstock (2009) advocates for the importance of career building skills in developing employability. Other elements included in her employability model are: self-management skills, discipline-specific skills and generic skills (Bridgstock, 2009, p. 36). Researchers Pool and Sewell (2007) proposed an alternative model of components of employability that combines all the main factors of USEM, but which is an easy and practical way explains the concept of employability and indicates that it is a "key" to choosing and securing occupations in which graduates have the opportunity to achieve satisfaction and success. The model explains the way in which five factors, namely, career development learning, experience, degree subject knowledge understanding, and skills, generic skills, and emotional intelligence can lead towards employability through a complex interaction with social concepts such as self-esteem, self-efficacy, and self-confidence. CareerEDGE model signifies an attempt to operationalize the concept of employability, unlike most previous studies which were either qualitative or case-study based which limited the application of findings (Sumanasiri, Yajid, \& Khatibi, 2015). The operationalization of the CareerEDGE model was performed by Pool, Qualter and Sewell in 2014 by exploring the factor structure of the model's employability development profile with the help of exploratory and confirmatory factor analyses. As a result, a list of 26 employability attributes was provided. 
A common element in all of these employability models developed by researchers is generic and transferable competencies which point to the consensus of researchers on the importance of these competencies to ensure the employability of graduates. The value of generic competencies for employers could be summarised as "give us bright and engaged graduate, and we will build specific expertise for this organization on top of that", as it has been formulated by Knight and Yorke (2002, p. 2). Similar trends in opinions have been identified also among Latvian employers, and the extent to which employers trust in educational achievements have been frequently questioned (Līce, 2017; Project and Quality Management Ltd., 2014).

In the second strand of the research focussing on the changing labour market, researchers pay special attention to education systems, their outcomes and economic returns, as well as new models of teaching and learning to address the needs of the future labour market. Quality of education, including of vocational education, is on special attention as it is contested concept with special stress to national qualification requirements (Zoellner, 2015) becoming more and more international even for the companies with only local capital. Another aspect which creates both challenges and opportunities for educational institutions is the raising participation age in education resulting from technological development, the flexibility of the labour market and ageing workforce. The more often stated question is - does education has a positive impact on attainment and on economic returns of qualifications (Acquah \& Huddleston, 2014)? It also creates deep discussions on models of education provision. Extensive analysis and evaluations are conducted towards a more systematic approach to continuing professional development in vocational education and training (Dymock \& Tyler, 2018). As the market is one of the most important driving forces for education development, modern approaches are designed and introduced to facilitate the development of transferable skills and employment mobility (Gekara \& Snell, 2018). Several other aspects are on academic researchers' agenda as well, including the role of capital, institutional and contextual factors that influence employability and career outcomes among graduates (Clarke, 2018). Those aspects are of great importance and are used in academic research worldwide. The research in this area should be continued to support evidence-based policy making in the field of education and employment.

\section{Empirical findings}

The employer survey was representative on the national level, it included employers of all main sectors, regions, sizes, with local and foreign capital, exporting and not exporting, as well as with the experience of having trainees during last 5 years and not. The overview of the number of respondents and share of companies in Latvia according to different categories is provided in Table 1.

Table 1. Number and Share of Respondents According to Categories: Sector, Region, Number of Employees, have had Trainees During the last 5 Years, Capital, Export (source: authors' calculations based on employer survey conducted in 2017. $\mathrm{n}=750$ )

\begin{tabular}{|c|c|c|c|c|c|}
\hline No. & Categorial variable & Description & $\begin{array}{l}\text { Number of } \\
\text { respondents }\end{array}$ & $\begin{array}{l}\text { Share of re- } \\
\text { spondents } \\
(\%) \text { in sample }\end{array}$ & $\begin{array}{l}\text { Share of companies } \\
(\%) \text { in Latvia accord- } \\
\text { ing to Central Statisti- } \\
\text { cal Bureau data (2015) }\end{array}$ \\
\hline 1.1 & Sector & $\begin{array}{l}\text { Production (NACE } 2 \text { codes: A, B, } \\
\text { C, D, E) }\end{array}$ & 162 & 21.60 & 13.8 \\
\hline 1.2 & & Trade (NACE2 codes: G) & 114 & 15.20 & 26.1 \\
\hline 1.3 & & Construction (NACE2 codes: F) & 54 & 7.20 & 8.9 \\
\hline 1.4 & & $\begin{array}{l}\text { Services (NACE2 codes: H, I, J, } \\
\text { K, L, M, N, P, Q, R, S) }\end{array}$ & 420 & 56.00 & 51.3 \\
\hline 2.1 & Region & Riga & 338 & 45.07 & 55.0 \\
\hline 2.2 & & Riga suburb & 122 & 16.27 & \multirow[t]{5}{*}{45.0} \\
\hline 2.3 & & Vidzeme & 70 & 9.33 & \\
\hline 2.4 & & Kurzeme & 76 & 10.13 & \\
\hline 2.5 & & Zemgale & 72 & 9.60 & \\
\hline 2.6 & & Latgale & 72 & 6.60 & \\
\hline 3.1 & $\begin{array}{l}\text { Number of Employ- } \\
\text { ees }\end{array}$ & $1-9$ & 467 & 62.27 & 88.2 \\
\hline 3.2 & & $10-49$ & 183 & 24.40 & 9.7 \\
\hline \multirow[t]{2}{*}{3.3} & & $50-249$ & 65 & 8.67 & 1.8 \\
\hline & & 250 or more & 35 & 4.67 & 0.3 \\
\hline
\end{tabular}


End of Table 1

\begin{tabular}{|c|c|c|c|c|c|}
\hline No. & Categorial variable & Description & $\begin{array}{l}\text { Number of } \\
\text { respondents }\end{array}$ & $\begin{array}{l}\text { Share of re- } \\
\text { spondents } \\
(\%) \text { in sample }\end{array}$ & $\begin{array}{l}\text { Share of companies } \\
(\%) \text { in Latvia accord- } \\
\text { ing to Central Statisti- } \\
\text { cal Bureau data (2015) }\end{array}$ \\
\hline 4.1 & $\begin{array}{l}\text { Have had Trainees } \\
\text { During the last } 5 \\
\text { years }\end{array}$ & Yes & 354 & 47.60 & $\mathrm{n} / \mathrm{a}$ \\
\hline 4.2 & & No & 394 & 52.53 & $\mathrm{n} / \mathrm{a}$ \\
\hline 4.3 & & Did not provide information & 2 & 0.27 & $\mathrm{n} / \mathrm{a}$ \\
\hline 5.1 & $\begin{array}{l}\text { Local or foreign } \\
\text { capital }\end{array}$ & Local & 678 & 90.40 & $\mathrm{n} / \mathrm{a}$ \\
\hline 5.2 & & Local and foreign & 36 & 4.80 & $\mathrm{n} / \mathrm{a}$ \\
\hline 5.3 & & Foreign & 36 & 4.80 & $\mathrm{n} / \mathrm{a}$ \\
\hline 6.1 & Exporting & Yes & 206 & 27.47 & $\mathrm{n} / \mathrm{a}$ \\
\hline 6.2 & & No & 531 & 70.80 & $\mathrm{n} / \mathrm{a}$ \\
\hline 6.3 & & Difficult to answer & 13 & 1.73 & $\mathrm{n} / \mathrm{a}$ \\
\hline
\end{tabular}

As it can be seen from the Table 1, the largest part of respondents operate in services, are based in Riga, are micro or small companies, have local capital and do not export. Almost equal number of respondents have had trainees during the last 5 years and have had no trainees during the last five years.

The results of employers' evaluations of the importance of employability attributes in the recruitment process show that the list of employability attributes, developed based on CareerEDGE employability attributes by Pool et al. (2014), is very important in recruitment in Latvia. The overall number of positive evaluations (10436 or $84 \%$ ) 5.25 times exceeded the number of negative evaluations (1988 or 16\%). The significant level of the importance of the employability competencies in the Latvian labour market indicates that employers are concerned with the changing labour market conditions are looking for employees able to cope with them. The main statistical indicators of employers' evaluations on the each of employability attribute are provided in Table 2. Relative frequencies of all positive and negative evaluations are included in Figure 1.

Table 2. Descriptive Statistics of Employer Evaluations of the importance of Employability Attributes (source: authors' calculations based on employer survey conducted in 2017, evaluation scale 1-4, where 1-2 - negative evaluations; 3-4 - positive evaluations. Additional option - "difficult to answer" (NA) was included. $\mathrm{n}=750$ )

\begin{tabular}{|c|l|c|c|c|c|c|c|c|c|c|}
\hline & \multicolumn{1}{|c|}{ Employability Attribute } & Median & Mean & SE of Mean & Mode & SD & Range & Min & Max & NA \\
\hline 1 & Attitude to work & 3 & 3.86 & 0.02 & 4 & 0.35 & 3 & 1 & 4 & 16 \\
\hline 2 & Ability to work independently & 4 & 3.60 & 0.02 & 4 & 0.53 & 3 & 1 & 4 & 14 \\
\hline 3 & Work motivation & 3 & 3.53 & 0.03 & 3 & 0.57 & 3 & 1 & 4 & 20 \\
\hline 4 & Responsibility for own decisions & 4 & 3.58 & 0.02 & 4 & 0.61 & 3 & 1 & 4 & 14 \\
\hline 5 & Problem solving skills & 3 & 3.46 & 0.03 & 3 & 0.60 & 3 & 1 & 4 & 20 \\
\hline 6 & Easily adapt to new situations & 4 & 3.43 & 0.02 & 4 & 0.60 & 3 & 1 & 4 & 13 \\
\hline 7 & Work in a team & 4 & 3.53 & 0.02 & 4 & 0.62 & 2 & 2 & 4 & 13 \\
\hline 8 & Communication skills & 4 & 3.43 & 0.01 & 4 & 0.65 & 3 & 1 & 4 & 13 \\
\hline 9 & Target orientation & 3 & 3.27 & 0.03 & 3 & 0.68 & 3 & 1 & 4 & 27 \\
\hline 10 & Planning and organizing skills & 3 & 3.23 & 0.03 & 3 & 0.73 & 3 & 1 & 4 & 20 \\
\hline 11 & Computer skills & 3 & 3.21 & 0.03 & 3 & 0.83 & 3 & 1 & 4 & 39 \\
\hline 12 & Create new ideas & 3 & 3.12 & 0.03 & 3 & 0.75 & 3 & 1 & 4 & 23 \\
\hline 13 & Relevant work experience & 4 & 2.91 & 0.02 & 4 & 0.81 & 3 & 1 & 4 & 16 \\
\hline 14 & Mathematical skills & 3 & 2.83 & 0.03 & 3 & 0.81 & 3 & 1 & 4 & 30 \\
\hline 15 & Clarity for career goals & 4 & 2.70 & 0.02 & 4 & 0.81 & 3 & 1 & 4 & 16 \\
\hline 16 & Presentation skills & 3 & 2.72 & 0.03 & 4 & 0.91 & 3 & 1 & 4 & 17 \\
\hline 17 & $\begin{array}{l}\text { Achievements in the education } \\
\text { academic skills) }\end{array}$ & 3 & 2.64 & 0.03 & 3 & 0.84 & 3 & 1 & 4 & 15 \\
\hline
\end{tabular}


Data of Table 2 and Figure 1 indicate that the most important employability attribute for employers is "attitude to work" with the highest arithmetic mean and the lowest indicators of variability (lowest standard deviation and standard error of the mean). Although the most often given evaluation for "attitude to work" was 4 (mode), full scale of evaluations (1-4) was covered for almost all analysed aspects besides "work in a team" where the lowest evaluation was 2. Half of the respondents gave evaluations of 3 or more in the scale 1-4 and half of the respondents gave evaluations of 3 or less (characterised by median). The second higher evaluated aspect was "ability to work independently" with very high evaluations and one of the smallest standard deviations indicating that employers' evaluations were with smaller variability than most of the other evaluated aspects.

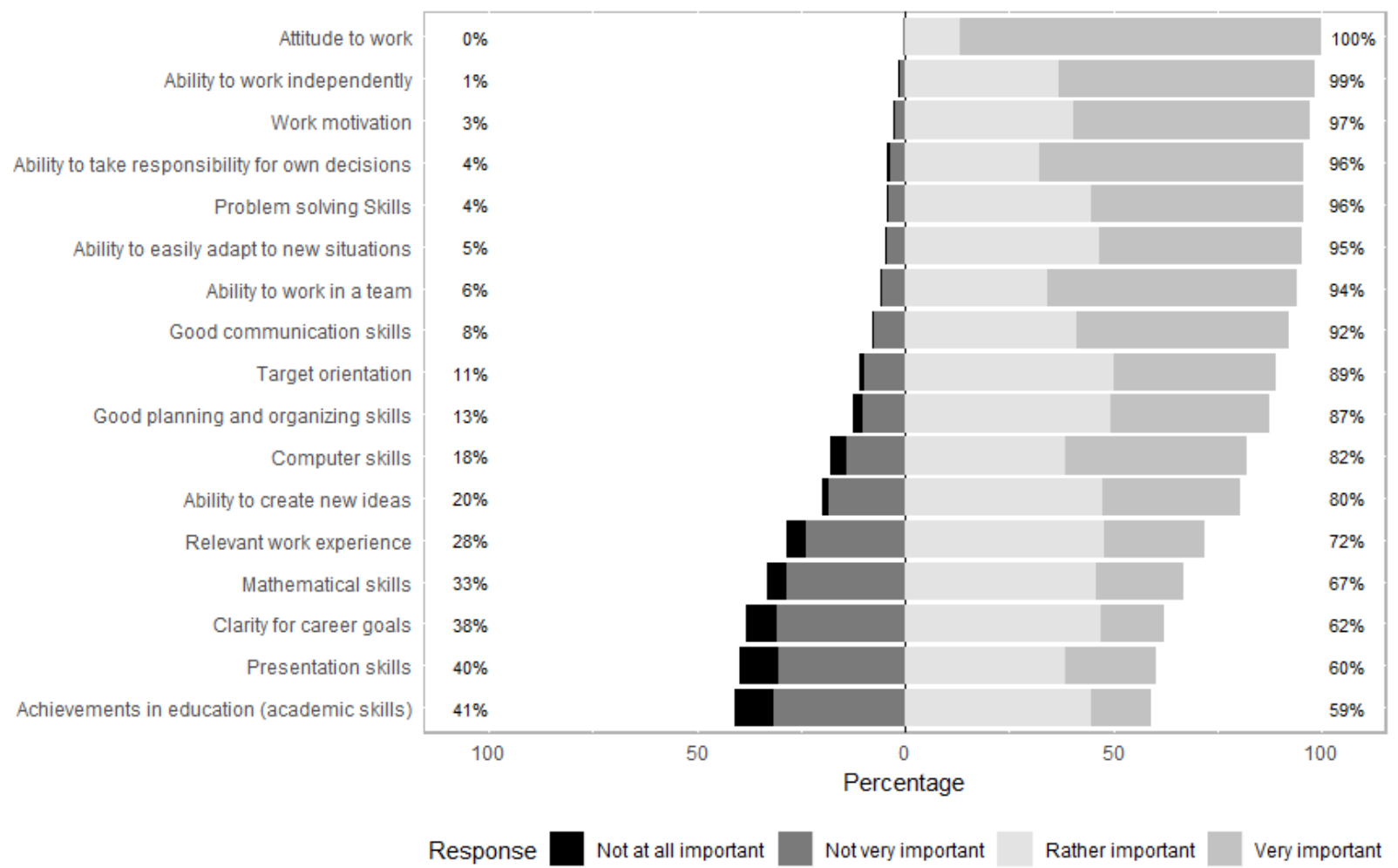

Figure 1. Employer Evaluation of the importance of Employability Attributes in the Recruitment Process. Relative Frequencies of Negative and Positive Evaluations. $n=750$ (source: authors' calculations based on employer survey conducted in 2017, evaluation scale 1-4, where 1-2 - negative evaluations; 3-4 - positive evaluations. Additional option - "difficult to answer" (NA) was included. $\mathrm{n}=750$ )

Next most positively evaluated employability attributes are closely linked to attitudes and type of personality, emotional and self-management competencies, for example "ability to work independently" (arithmetic mean of evaluations by respondents 3.60, standard deviation of 0.53), "work motivation" (arithmetic mean of evaluations by respondents 3.53, standard deviation of 0.57 ) and "ability to take responsibility for own decisions" (arithmetic mean of evaluations by respondents 3.58 , standard deviation of 0.61 ), which are closely followed by "ability to adapt to new situations" (arithmetic mean of evaluations by respondents 3.43, standard deviation of 0.60 ). In descending order of the importance, these are followed by competencies which are liked to communication and cooperation, including problem solving skills, work in a team, communication skills.

According to employers, achievements in education (academic skills) is the least important element in the list of employability attributes with arithmetic mean of evaluations by respondents 2.64 and a standard deviation of 0.84 . In scientific literature very much discussed aspect "presentation skills" had one of the lowest average evaluations by employers but the highest variability in evaluations (characterised by standard deviation). "Relevant work experience" and "mathematical skills" also received comparatively lower evaluations which indicates the tendency for employers to value attitudes, emotional, self-management and social competencies more than prior education or work achievements. Nevertheless, work experience and achievements in education should not be considered unimportant in the eyes of employers as the number of positive evaluations still exceed negative evaluations. Moreover, high achievements in education and work experience gained are good indicators of the personal traits and are linked to many of the other employability attributes. The difference lies in the aspect that a person with good education and experience is more likely to possess the desired attitudes and competencies, but not necessarily. A person with desired attitudes and competencies, however, does not necessarily has a convincing record of prior education and experience. Therefore, the choice of employers indicates towards the preference of "learning outcomes" over the "input-based" employability 
attributes. This is favourable for young people without work experience or for those who have not completed education degree, as they still have good chances in the Latvian labour market to show their potential than it might be possible in other, more regulated and conservative labour markets. It should be noted, however, that it is very difficult to measure or predict attitudes and competencies in potential employees, comparing to work experience or education degree obtained. This might be one of the explanations why personal recommendations are very important for employers in Latvia in the recruitment process.

The research showed that the opinion among different groups of employers might differ. Kruskal-Wallis test or one-way ANOVA test showed statistically significant differences in opinions among companies from different sectors (at a significance level of 0.01 , p-value $=0.003988$ ), among companies with different number of employees (at the significance level of 0.01 , p-value $=4.344 \mathrm{e}-08$ ), among companies with local or foreign capital (at the significance level of 0.01 , p-value $=0.006669$ ), as well as among companies which had or had not trainees (at the significance level of 0.01 , p-value $<2.2 \mathrm{e}-16$ ). Figure 2 shows the distribution of employer evaluations of the importance of employability attributes in the recruitment process.

I

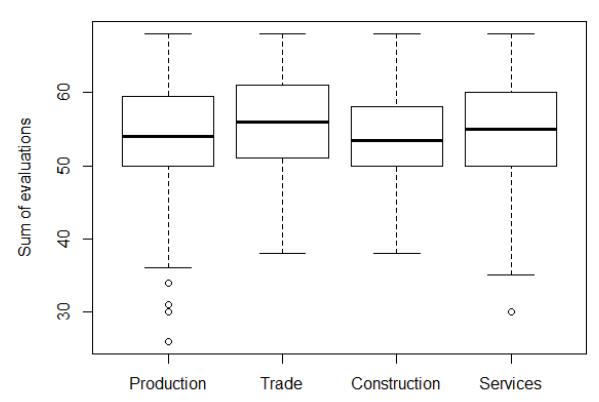

III

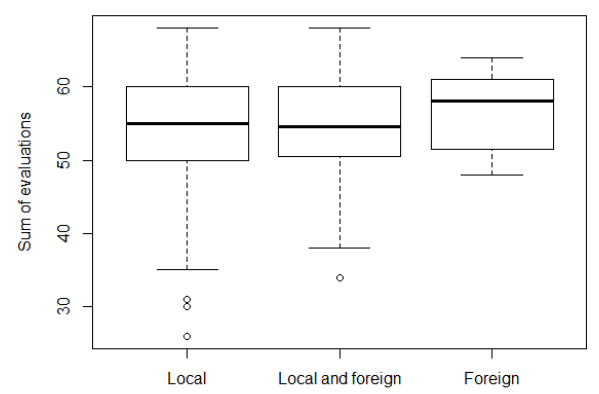

II

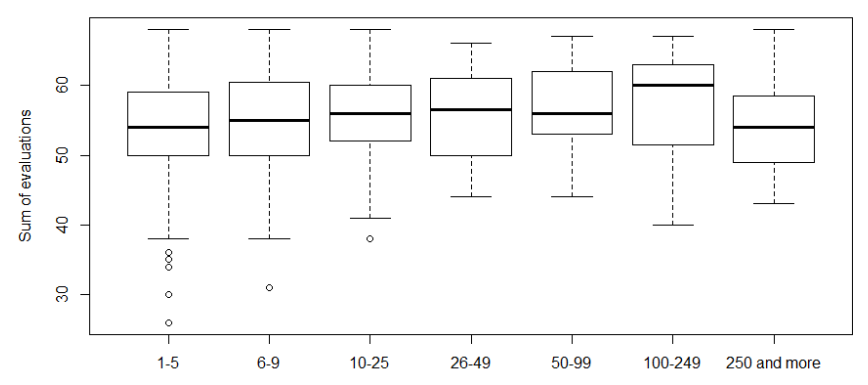

IV

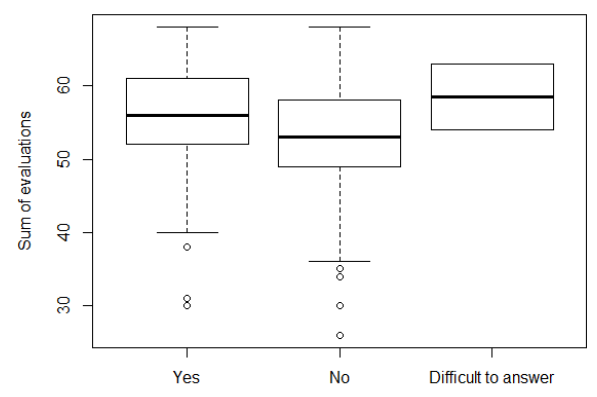

Figure 2. Graphical Representation of Distribution of Employer Evaluations of the importance of Employability Attributes in the Recruitment Process According to Different Criteria: I - Sector; II - Number of Employees; III - Local of Foreign Capital; IV - have had Trainees during Last 5 Year; have had not Trainees during Last 5 Years or could not Answer (source: authors' calculations based on employer survey conducted in 2017. $\mathrm{n}=750$ )

As it can be seen in Figure 2, the importance of employability competencies is higher in companies which operate in trade and services sectors, comparing to companies operating in manufacturing and construction sectors, in companies with 100-249 employees, with foreign capital and which have had trainees during last 5 years.

Kruskal-Wallis test or one-way ANOVA didn't show a statistically significant difference in opinions among companies in different regions $(\mathrm{p}$-value $=0.6502)$ and among companies which are or are not exporting $(\mathrm{p}$-value $=$ $0.2171)$.

In the factor analysis of employer evaluations of the importance of initial 17 employability attributes in the recruitment process, three complex factors were identified by extraction method of principal components analysis, converted in 5 iterations using the rotation method - Varimax with Kaiser normalisation. Results of factor analysis of employers' evaluations are included in Table 3. 
Table 3. Employability Attribute Complex Factors Obtained in Factor Analysis - Rotated Component Matrix (source: authors' calculations based on employer survey conducted in 2017, evaluation scale 1-4, where 1-2 - negative evaluations; 3-4 - positive evaluations. Additional option - "difficult to answer" (NA) was included. $\mathrm{n}=750$ )

\begin{tabular}{|c|c|c|c|}
\hline \multirow{2}{*}{ Employability Attribute } & \multicolumn{3}{|c|}{ Component } \\
\hline & $\mathrm{F}_{1}$ & $\mathrm{~F}_{2}$ & $\mathrm{~F}_{3}$ \\
\hline Easily adapt to new situations & 0.601 & 0.269 & -0.046 \\
\hline Communication skills & 0.727 & 0.205 & -0.075 \\
\hline Create new ideas & 0.590 & 0.248 & 0.312 \\
\hline Responsibility for own decisions & 0.420 & 0.530 & 0.138 \\
\hline Presentation skills & 0.692 & 0.056 & 0.196 \\
\hline Ability to work independently & 0.144 & 0.754 & 0.082 \\
\hline Work in a team & 0.229 & 0.650 & 0.232 \\
\hline Attitude to work & 0.098 & 0.644 & 0.010 \\
\hline Achievements in education (academic skills) & 0.119 & -0.017 & 0.784 \\
\hline Planning and organizing skills & 0.557 & 0.209 & 0.356 \\
\hline Clarity for career goals & 0.366 & 0.109 & 0.671 \\
\hline Target orientation & 0.502 & 0.317 & 0.415 \\
\hline Work motivation & 0.253 & 0.582 & 0.282 \\
\hline Mathematical skills & 0.152 & 0.185 & 0.500 \\
\hline Problem solving skills & 0.504 & 0.429 & 0.186 \\
\hline Computer skills & 0.453 & 0.063 & 0.387 \\
\hline Relevant work experience & -0.253 & 0.304 & 0.571 \\
\hline \multicolumn{4}{|c|}{$\begin{array}{l}\text { Extraction Method: Principal Component Analysis. } \\
\text { Rotation Method: Varimax with Kaiser Normalization. }\end{array}$} \\
\hline
\end{tabular}

Complex factor F1 was named "Professional skills", complex factor F2 - "Attitude and ability skills" where initial factors had the strongest correlation with the second complex factor being more than 0.5 , and complex factor $\mathrm{F}_{3}$ - "Work experience and education achievements". Therefore, the number of attributes describing individual employability can be reduced simplifying their use in further research or practice, helping different groups of stakeholders to understand the core elements of individual employability.

\section{Discussion}

The high evaluation by employers of the importance of the list of employability attributes developed based on CareerEDGE model by Pool et al. (2014), in the recruitment process in Latvia, shows that the labour market demands in Latvia reflect global tendencies in future skills needs. It also shows that skills, competencies and attitudes which help employees to be more employable in changing labour market, including to find fulfilling employment and to change jobs easier, are also highly valued by employers in the recruitment process in Latvia. It means that employers seriously consider the need to adapt to changing markets and are looking for employees being able to adapt and to facilitate organizational change.

Comparatively low importance of achievements in education for employers is confirmed also in other research (e.g., Klāsons, Pavlina, Danneberg, \& Urb, 2018, about Latvia and Estonia). It should be noted, however, that there is evidence that high academic performance is linked to proactive personalities (Ruge \& McCormack, 2017) and the level of education obtained - to participate in lifelong learning (e.g., European Commission, 2015). People with high academic skills are motivated to invest more in their skills improvement what could be reasonable taking into account increasing requirements for employee skills and participation in lifelong learning. The low evaluation of the importance of academic performance might be explained by the low trust in the education system in Latvia, a preference towards real "learning outcomes" over the "input-based" employability attributes, as well as readiness to invest in competency development of employees themselves. For the latter, readiness and motivation of employees to learn and to adapt is 
very important, which is in line with employers' evaluation of the importance of employee attitudes. This conclusion is also in line with the results of other employer surveys (e.g., Līce, 2017; Project and Quality Management Ltd., 2014).

Although the overall evaluation of the importance of employability attributes is very high, some groups of employers valued employability attributes in the recruitment process significantly higher than others: employers which have had trainees during last 5 years, employers which have 100-249 employees, and which have foreign capital. Considering the profile and engagement of these employers in educational activities, this might be linked to their practice of more pronounced planning in the long-term and the stability of operation which is less common to small companies. Undoubtedly, the goal of being adaptable to changing labour market conditions requires long-term approach to human resource planning and readiness to invest in the education of employees.

This study also offers the model of reducing a number of employability attributes to three complex factors, based on the results of one of the most effective multivariate analysis methods for dimension reduction - factor analysis. The three complex factors are: professional skills, attitude and ability skills and work experience and education achievements. This allows to better explain the elements of individual employability and the main priorities of employers in the recruitment process to a wider audience: recruiters, career consultants, educational institutions and students.

\section{Conclusions}

This research has evaluated, which skills, competencies and attitudes are most important in the recruitment process in Latvia from employers' perspective. The employers highly value attitudes and competencies that allow individuals to flexibly adapt to changes in the labour market, especially emotional, self-management and social competencies. The most valued is the attitude to work, ability to work independently and work motivation. Compared to other individual attributes, employers are least likely to appreciate achievements in education (academic skills) which was important for $60 \%$ of employers. Importance of employability competencies is higher in companies which operate in trade and services sectors, comparing to companies operating in manufacturing and construction sectors, in companies with 100 249 employees, with foreign capital and which have had trainees during last 5 years. Individual attributes determining employability could be summarised into three complex employability factors: professional skills; attitude and ability skills; and work experience and education achievements. The results of the research have implications for different stakeholders in the area of human resource planning and development as they allow to better explain the elements of individual employability and the main priorities of employers in the recruitment process.

\section{Disclosure statement}

Authors do not have any competing financial, professional, or personal interests from other parties with regards to research results.

\section{References}

Acquah, D. K., \& Huddleston, P. (2014). Challenges and opportunities for vocational education and training in the light of Raising the Participation Age. Research in PostCompulsory Education, 19(1), 1-17. https://doi.org/10.1080/13596748.2013.872915

Bridgstock, R. (2009). The graduate attributes we've overlooked: enhancing graduate employability through career management skills. Higher Education Research \& Development, 28(1), 31-44. https://doi.org/10.1080/07294360802444347

Clarke, M. (2018). Rethinking graduate employability: the role of capital, individual attributes and context. Studies in Higher Education, 43(11), 1923-1937. https://doi.org/10.1080/03075079.2017.1294152

Dymock, D., \& Tyler, M. (2018). Towards a more systematic approach to continuing professional development in vocational education and training. Studies in Continuing Education, 40(2), 198-211. https://doi.org/10.1080/0158037X.2018.1449102

European Commission. (2015). Education and training monitor 2015. Luxembourg. Retrieved from http://ec.europa.eu/dgs/education_culture/repository/education/library/publications/monitor15_en.pdf

Fugate, M., Kinicki, A. J., \& Ashforth, B. E. (2004). Employability: A psycho-social construct, its dimensions, and applications. Journal of Vocational Behavior, 65(1), 14-38. https://doi.org/10.1016/j.jvb.2003.10.005

Gekara, V., \& Snell, D. (2018). Designing and delivering skills transferability and employment mobility: the challenges of a marketdriven vocational education and training system. Journal of Vocational Education \& Training, 70(1), 107-129. https://doi.org/10.1080/13636820.2017.1392996

Harvey, L. (1999, October). Employability: Developing the relationship between higher education and employment. In Opening presentation at the Fifth Quality in Higher Education 24-Hour Seminar. Warwick: University of Central England in Birmingham, Centre for Research into Quality. Retrieved from http://qualityresearchinternational.com/esecttools/relatedpubs/Employability5thQHE.pdf

Harvey, L. (2005). Embedding and integrating employability. New Directions for Institutional Research, 2005(128), 13-28. https://doi.org/10.1002/ir.160

Humburg, M., van der Velden, R., \& Verhagen, A. (2013). The employability of higher education graduates: The employers' perspective. Publications Office of the European Union. https://doi.org/10.2766/54258 
Klāsons, G., Pavlina, A., Danneberg, T., \& Urb, K. (2018). Skills required in the labour market: using job advertisements to identify skills requirements in the labour market. Pilot study report. Retrieved from https://juc.lv/wp-content/uploads/2017/07/BizzSkillSet_Study-Report_2018_ENG.pdf

Knight, P., \& Yorke, M. (2002). Assessment, learning and employability. The Society for Research into Higher Education \& Open University Press.

Līce, A. (2017). Involvement of employers in educating employees as a solution to the problem of skilled workforce shortage in Latvia. In I. Kangro, A. Fernāte, S. Kārkliṇa, \& S. Kraže (Eds.), Challenges for High Quality of Adult Education: Inter-national Scientific Conference Proceedings (pp. 111-123). Riga: Ministry of Education and Science.

Pool, L. D., Qualter, P., \& Sewell, P. J. (2014). Exploring the factor structure of the CareerEDGE employability development profile. Education + Training, 56(4), 303-313. https://doi.org/10.1108/ET-01-2013-0009

Pool, L. D., \& Sewell, P. (2007). The key to employability: Developing a practical model of graduate employability. Education + Training, 49(4), 277-289. https://doi.org/10.1108/00400910710754435

Project and Quality Management Ltd. (2014). Darba tirgus specifisko regionālo problēmu identificēšana un pasākumu izstrādāšana reǵionālā darba tirgus konkurētspējas stiprināšanai, pētījuma atskaite [Identification of specific regional labor market problems and identification of measures for strengthen its competitiveness, the study report]. Retrieved from http://www.nva.gov.lv/docs/28_53abbd7c02ee19.16060069.pdf

Ruge, G., \& McCormack, C. (2017). Building and construction students' skills development for employability - reframing assessment for learning in discipline-specific contexts. Architectural Engineering and Design Management, 13(5), 365-383. https://doi.org/10.1080/17452007.2017.1328351

Sumanasiri, E. G. T., Yajid, M. S. A., \& Khatibi, A. (2015). Review of literature on Graduate Employability. Journal of Studies in Education, 5(3), 75. https://doi.org/10.5296/jse.v5i3.7983

World Economic Forum. (2018). The future of jobs report. 2018. Switzerland. Retrieved from http://www3.weforum.org/docs/WEF_Future_of_Jobs_2018.pdf

Yorke, M., \& Knight, P. (2004). Embedding employability into the curriculum. Learning and Employability, 3, 1-28.

Zoellner, D. (2015). Quality in vocational education and training: an essentially contested concept. International Journal of Training Research, 13(3), 262-271. https://doi.org/10.1080/14480220.2015.1102469 